\title{
INDOMETHACIN IN RHEUMATIC DISEASES A CONTROLLED CLINICAL TRIAL
}

\author{
BY
}

\author{
J. WANKA, L. I. JONES, PHILIP H. N. WOOD,* AND ALLAN ST. J. DIXON \\ From the Rheumatism Departments of St. Stephen's Hospital, \\ St. Mary Abbots Hospital, and Hammersmith Hospital, London
}

Indomethacin (1-(p-chlorbenzoyl)-5-methoxy-2methylindole-3-acetic acid) (Fig. 1) is a compound which has been shown to have anti-inflammatory and antipyretic action in experimental animals (Hodgkinson, 1963). Enthusiastic but largely uncontrolled studies of its action in rheumatoid arthritis and other disorders have been reported (see Proceedings of the American Rheumatism Association, 1963) and more recently reports of its therapeutic value have been published in Great Britain (Hart and Boardman, 1963). This paper reports experiences with this drug over the last year in the treatment of rheumatoid arthritis and other conditions. The study was conducted in three parts:

(1) A double-blind weekly crossover clinical trial comparing indomethacin against an identical placebo tablet in 22 patients with rheumatoid arthritis.

(2) A study of the effects of continuous administration in $\mathbf{4 3}$ patients, ten of whom had participated in the double-blind trial.

(3) A study of the effect of indomethacin on gastrointestinal bleeding in fourteen patients.<smiles>COc1ccc2c(c1)[C@H](CC(=O)O)[C@H](C)[C@H]2C(=O)c1ccc(Cl)cc1</smiles>

INDOMETHACIN

Fig. 1.-Chemical formula of

1-(p-chlorbenzoyl)-5-methoxy-2-methylindole-3-acetic acid (Indomethacin).

Particular attention was paid to the incidence of toxic effects, since Stone (1962) reported that the drug may cause gastrointestinal haemorrhage in animals.

* Present address: Departments of Medicine, Veterans Administration Hospital and State University of New York at Buffalo, Buffalo, N.Y., U.S.A.
In trials of this drug on ourselves and in patients we noticed that a disabling headache could sometimes occur.

\section{(1) THE DOUBLE-BLIND TRIAL}

22 patients with definite rheumatoid arthritis (A.R.A. criteria-Ropes, Bennett, Cobb, Jacox, and Jessar, 1957) with inflammation (as judged by heat, swelling, redness, and tenderness) of one or more joints were admitted to the trial. They were allocated at random to start treatment with either placebo or indomethacin; fourteen patients (Cases 3, $4,5,8,11,12,13,14,15,16,18,19,20,21)$ started on active tablets and eight (Cases 1, 2, 6, 7, 9, 10, 17, 22) on placebo therapy (Fig. 2, opposite). At the end of each week the tablet containers were collected, any unused tablets counted and a container of alternative tablets issued. Treatment was accepted as adequate if at least 70 per cent. of the prescribed dose had been taken. This alternation of placebo and active drug was continued for 6 weeks (two patients-Cases 17 and 20-stopped participation after 4 weeks), and the same observer saw the patient at the end of each week. The dosage used was 100 mg. twice daily in ten patients and $100 \mathrm{mg}$. three times daily in twelve patients.

Every week the patients' haemoglobin concentration, white cell count, sedimentation rate, blood urea and liver function tests (serum bilirubin, flocculation tests, serum transaminases, and serum alkaline phosphate) were estimated and a specimen of urine examined. A Waaler-Rose test was done at the beginning and end of the trial. Grip strength was recorded weekly. Untoward symptoms which were volunteered were recorded but side-effects were not specifically asked for. Possible toxic signs were recorded. The patient's assessment of his own progress was sought at the end of each week, and each patient was invited to state whether the amount of joint pain and stiffness experienced was "less", "the same", or "worse" as compared with the previous week. Fig. 3 (overleaf) summarizes the position as regards the patient's preference at the 

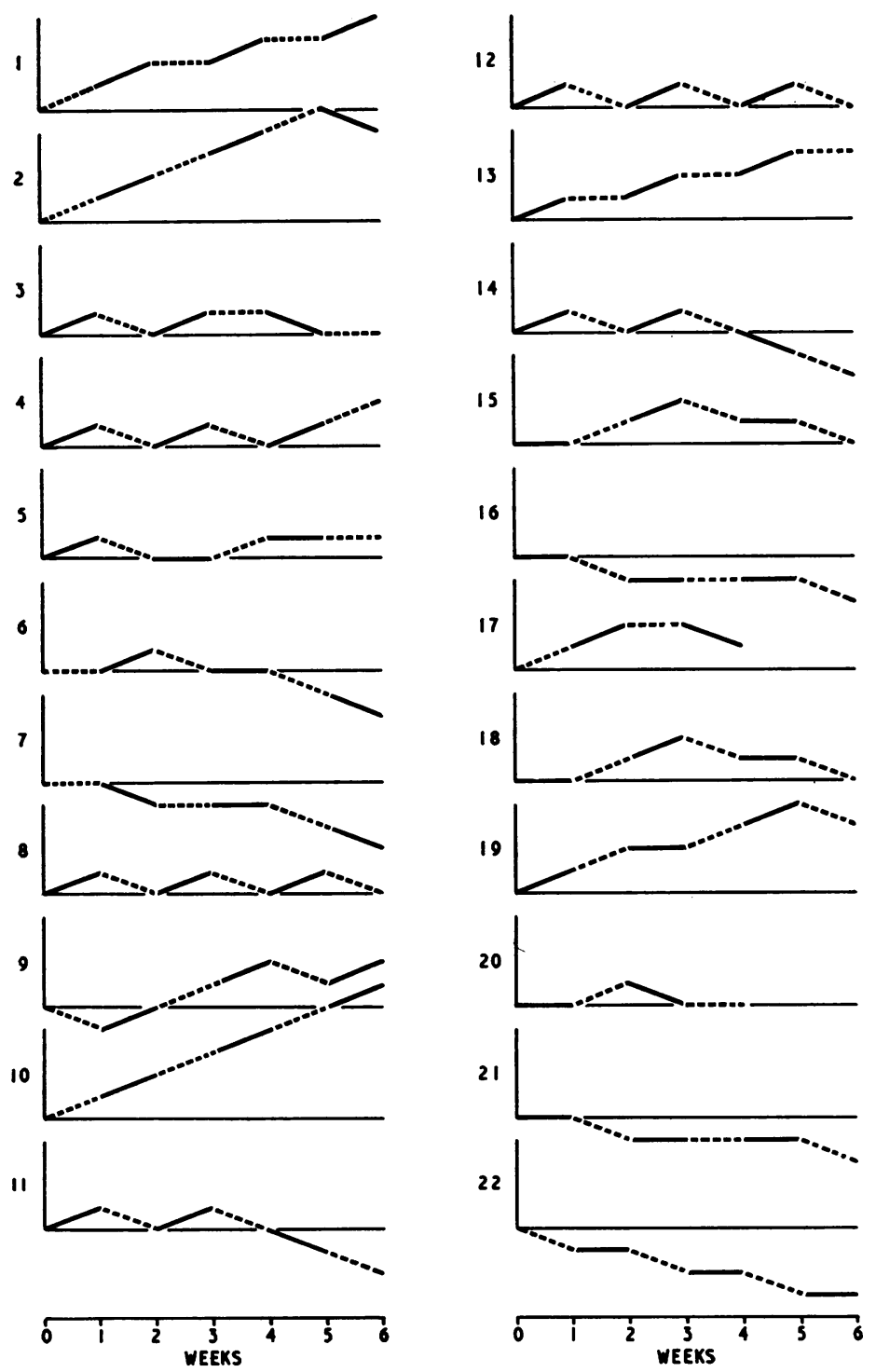

INDOMETHACIN

PLACEBO

Fig. 2.-Progress observed in 22 cases during a period of 6 weeks. A continuous line represents a week on indomethacin, an interrupted line a week on placebo. The line rises, stays level, or falls according to whether the patient's symptoms are better, the same or worse at the end of a week's treatment.

end of each week. "Net preference" is derived from the whole 6 weeks' picture. Three types of positive response can be made out, exemplified by Cases 1, 12, and 22 in Fig. 2.

Case 1: Those who regard themselves as improved on indomethacin and "the same" on the placebo (when this is consistent, the chart shows a stepwise rise).
Case 12: Those who are improved on indomethacin and "worse" while on placebo (the chart shows a picket-fence pattern).

Case 22: Those who are "the same" on active drug and are "worse" on placebo (the chart shows a stepwise fall).

These patterns probably represent an identical situation but modified by the patients' outlook 
corresponding to the placebo-positive and placebonegative concepts of Joyce (1961). Case 10 is so strongly placebo-positive that she regards herself as "better" each week irrespective of treatment. The net preference at the end of 6 weeks was charted by the method of Bross (1952) for sequential analysis (Fig. 3).

\section{PATIENT PREFERENCE}

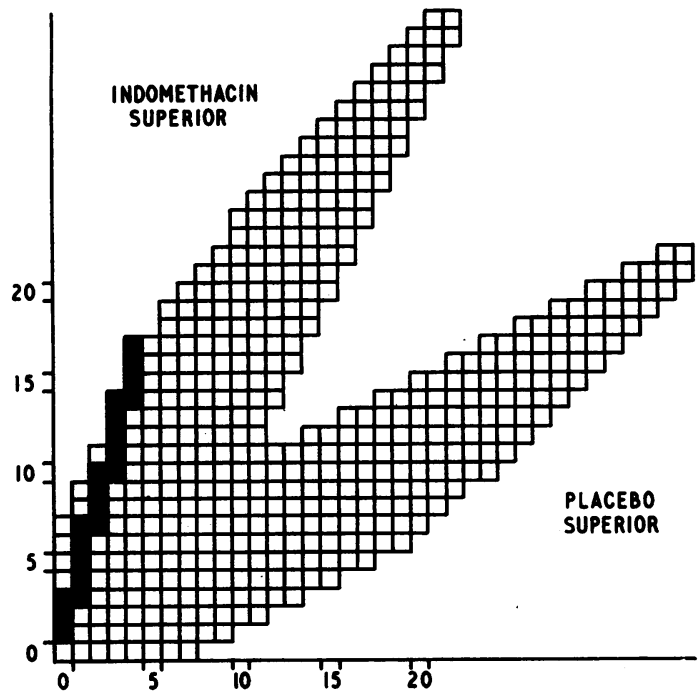

Fig. 3.-Net preference for indomethacin against an inert placebo. Each square represents one patient's net preference over the whole 6 weeks period of the trial. If the patient prefers indomethacin the square is charted in the direction of the ordinate. If he prefers the placebo the square is charted in the direction of the abscissa. (After Bross (1952). Biometrics, 8, 188).

\section{Results}

Net preference for indomethacin was shown by seventeen patients, and net preference for placebo by four; the results were inconclusive in one patient.

In the majority the strength of grip showed no change as long-standing deformities were the limiting factor. However, one patient (Case 21) showed consistent alternation of grip-strength, improving on indomethacin and deteriorating again while on placebo (Fig. 4).

The results of the laboratory tests were all normal and showed no alternation with treatment.

The toxic effects (Table I) are expressed in "patientweeks of treatment". Headaches occurred in 27 out of 64 weeks on indomethacin and in 15 out of 64 weeks on placebo. The headache usually began within an hour of taking the tablet and might persist for 24 hours or even longer although no further tablets were taken. Because of this persistence, indomethacin headaches might carry over into and be counted in the control period. Sometimes, if

TABLE I

TOXIC EFFECTS ENCOUNTERED DURING INDOMETHACIN THERAPY IN PATIENTS ON DOUBLE-BLIND CONTROLLED TRIAL

\begin{tabular}{|c|c|c|c|c|c|}
\hline & & & & \multicolumn{2}{|c|}{ Patient-Weeks of Treatment (64) } \\
\hline \multicolumn{3}{|c|}{ Toxic Effects } & & Indomethacin & Placebo \\
\hline $\begin{array}{l}\text { Headache } \\
\text { Giddiness } \\
\text { Nausea } \\
\text { Vomiting } \\
\text { Tinnitus }\end{array}$ & $\begin{array}{l}. \\
\cdots \\
\cdots \\
\ldots\end{array}$ & $\begin{array}{l}\ldots \\
\ldots \\
\ldots \\
\ldots\end{array}$ & $\begin{array}{l}\ldots \\
\ldots \\
\ldots \\
\ldots \\
. .\end{array}$ & $\begin{array}{r}27 \\
11 \\
6 \\
5 \\
4\end{array}$ & $\begin{array}{r}15 \\
5 \\
6 \\
0 \\
0\end{array}$ \\
\hline
\end{tabular}


treatment were persevered with, the headache resolved spontaneously. Headaches were often accompanied by giddiness, which occurred in eleven out of 64 patient-weeks of treatment on indomethacin and in five out of 64 weeks on placebo tablets. Antihistamines partially relieved the headaches but not the giddiness. One patient was on one occasion noted to be slightly ataxic and had a positive Romberg sign. Nausea and vomiting were not a serious problem. Tinnitus occurred during four treatment/weeks on indomethacin. One patient developed an ulcer on the gum, which showed no response to local therapy but healed within 2 weeks of completion of the trial. (We have since noted this last complication in two other patients.) Both headaches and giddiness tended to be slightly more prominent on a dosage of $300 \mathrm{mg}$. indomethacin per day than on $200 \mathrm{mg}$. per day.

\section{(2) CONTINUOUS TREATMENT}

The total number of patients participating was 43, ten of whom had also taken part in the double-blind controlled trial; 33 were suffering from rheumatoid arthritis, two from an acute attack of gout, two from ankylosing spondylitis, two from osteo-arthritis of the hip, and one each from psoriatic arthropathy, polymyalgia rheumatica, erythema nodosum, and generalized osteo-arthritis.

In order to minimize the toxic effects, a gradually increasing dosage scheme was used:

$50 \mathrm{mg}$. twice daily on the first and second day,

$50 \mathrm{mg}$. three times daily on the third and fourth day,

$100 \mathrm{mg}$. twice daily on the fifth and sixth day of treatment.

The patient was then given a maintenance dose of 200-250 mg. indomethacin per day.

\section{Results}

Of the 33 patients with rheumatoid arthritis, ten had marked benefit from indomethacin (as shown by a decrease in the amount of pain and morning stiffness and an increase in their activities), nineteen showed some, though sometimes only temporary, improvement, and four patients derived no benefit at all.

In the few patients with conditions other than rheumatoid arthritis the response to indomethacin could generally be judged as good. In the patient with polymyalgia rheumatica the initial response was comparable with that obtained with ACTH, but she relapsed after a few days. The patient with erythema nodosum with severe arthralgia and periarticular swelling of both ankles and knees could distinguish indomethacin from placebo tablets and periarticular swelling and redness decreased during indomethacin therapy. Both patients with gout responded within an hour.

The period of observation varied from 4 to 40 weeks. No abnormalities in laboratory investigations were detected during this period.

The most prominent side-effect during indomethacin therapy, namely headache, was no less common in this than in the first trial, occurring at some time in half the patients. However, with the graduated dosage regime, it was less severe and all but two of those who reported headache were prepared to tolerate it in exchange for relief of their joint pains. Altogether six patients stopped taking the drug or it was stopped by the physician because of toxic effects, and three of the 33 patients with rheumatoid arthritis experienced an acute exacerbation of arthritis in one or more joints whilst on continuous treatment. Two patients stopped treatment because of headaches, two because of gastric intolerance, one had a perforated gastric ulcer (Case 23) while on indomethacin, and another patient a major gastrointestinal haemorrhage (Case 24).

\section{Case Reports}

Case 23, a woman aged 54, had suffered from rheumatoid arthritis since 1950. Corticosteroid treatment was commenced in 1957. In 1961 she first complained of dyspepsia and dysphagia. Two barium meal examinations in December, 1961, and March, 1962, revealed no peptic ulcer but a rolling-type hiatus hernia. An oesophagoscopy done at that time showed peptic oesophagitis. In February, 1963, signs of steroid overdosage were noted and the dose of prednisone was slowly reduced. This resulted in a generalized exacerbation of the arthritis. Treatment with indomethacin $100 \mathrm{mg}$. per day was started on April 24, 1963, and the dose of this drug was increased by $50 \mathrm{mg}$. every other day to $250 \mathrm{mg}$./day. The patient, when seen in the outpatients clinic, "felt marvellous, better than for ages" and some objective improvement of grip-strength had also occurred. She had experienced a slight headache. On her second visit to outpatients, 2 weeks later, she reported a short period of nausea, lasting 2 days during which she had left off indomethacin, but she was then well again and had restarted the drug. Occult blood was absent from the faeces on both visits. She failed to keep her next appointment, and on June 18,1963, was admitted with a 5-hour history of severe epigastric pain, preceded by 3 days of nausea and dyspepsia. At laparotomy a perforated anterior gastric ulcer was found. The perforation was closed and 6 weeks later the patient was readmitted and a partial gastrectomy performed (by Mr. Howard Jayne). No ulcer or scar could be seen in the resected specimen. Indomethacin was discontinued after the perforation. The patient is well but still complains of some dyspepsia, and is now on treatment with entericcoated prednisolone $10 \mathrm{mg}$. per day. 


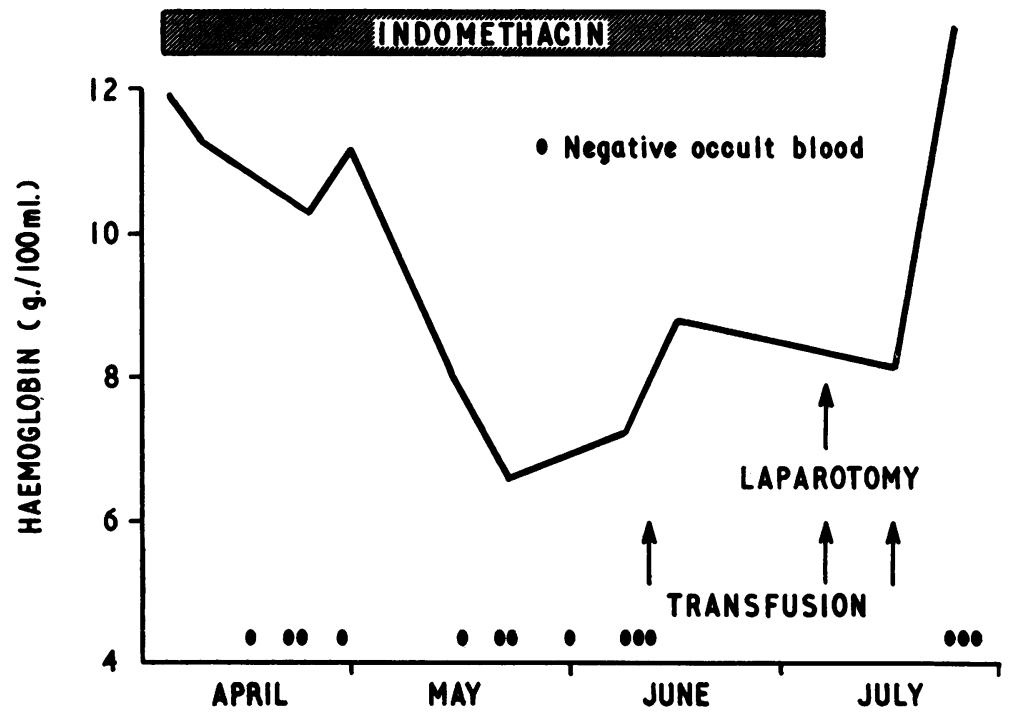

Fig. 5.-Progressive anaemia during treatment with indomethacin (Case 24).

Case 24, a woman aged 64, has suffered from rheumatoid arthritis since 1932. In early April, 1963, she was admitted with a very severe polyarthralgia of acute onset which was accompanied by an aspiration pneumonia, later complicated by a pleural effusion. She was treated initially with indomethacin $300 \mathrm{mg}$. daily, and tetracycline. The joint symptoms abated very well in the beginning, but she quickly relapsed and the dose of indomethacin was increased to $600 \mathrm{mg}$. daily. This again produced a good remission of the joint inflammation, but the patient developed abdominal pain and nausea, and the dose was reduced to $300 \mathrm{mg}$. indomethacin daily. The patient was then maintained on this dose, but it was noted that she became anaemic, for which no obvious explanation could be found, repeated biochemical estimations of the faecal occult blood loss all being negative (Fig. 5).

After blood transfusion she was discharged, but was re-admitted 2 weeks later with severe pre- and postprandial dyspepsia and anaemia. Shortly after admission she passed several melaena stools, and failed to settle on blood transfusion. At laparotomy (Mr. E. C. Chitty), no lesion to account for the bleeding could be seen or palpated in the stomach or duodenum. The stomach was not opened. The small intestine below the second part of the duodenum was distended with blood. All other intra-abdominal organs were normal. Postoperatively a barium meal examination was also reported as normal. The patient made an uneventful recovery and is now well.

\section{(3) GASTROINTESTINAL BLEEDING}

The third study consisted of the measurement of gastrointestinal bleeding in fourteen patients by labelling their erythrocytes with radioactive chromate. The method was the same as that used previously by this group (Scott, Porter, Lewis, and Dixon, 1961; Wood, Harvey-Smith, and Dixon, 1962), and the effect of indomethacin was compared with the effect of aspirin on the same patients. Significant blood loss is attributed to a drug only if

TABLE II

COMPARATIVE STUDIES OF FAECAL BLOOD IN 13 CASES AFTER ASPIRIN AND AFTER INDOMETHACIN

\begin{tabular}{|c|c|c|c|}
\hline \multirow{2}{*}{ Case No.* } & \multicolumn{2}{|c|}{ ml. Blood Loss per Day of Treatment } & \multirow{2}{*}{ Remarks } \\
\hline & Aspirin & Indomethacin & \\
\hline 25 & 4 & $1 \cdot 5$ & Also has duodenal \\
\hline $\begin{array}{l}26 \\
27 \\
18\end{array}$ & $\begin{array}{l}6 \\
3 \\
3 \cdot 5\end{array}$ & $\begin{array}{r}0 \\
<1 \\
0\end{array}$ & Duodenal ulcer 4 \\
\hline $\begin{array}{l}4 \\
1\end{array}$ & $\stackrel{3}{\text { not available }}$ & $\begin{array}{l}0 \\
4 \text { (Fig. 7) }\end{array}$ & $\begin{array}{l}\text { Allergic to aspirin, } \\
\text { previous gastrec- } \\
\text { tomy for peptic }\end{array}$ \\
\hline $\begin{array}{r}9 \\
28\end{array}$ & $\begin{array}{l}1 \\
3\end{array}$ & $2 \cdot 5$ & Barium meal \\
\hline $\begin{array}{l}29 \\
30 \\
31 \\
19 \\
32\end{array}$ & $\begin{array}{r}5 \\
4 \\
8 \\
12 \\
18\end{array}$ & $\begin{array}{l}2 \text { (Fig. 6) } \\
0 \\
0 \\
0 \\
2 \cdot 5\end{array}$ & 二 \\
\hline Mean & $5 \cdot 9$ & $1 \cdot 2$ & \\
\hline
\end{tabular}

* Cases 18, 4, 1, 9, and 19 are shown here with the numbers they bear in Fig. 2 . 
the stools are free from blood before the drug is administered and if the faecal radioactivity returns to basal levels some time after stopping the drug. By these criteria, the studies in one patient could not be interpreted; the results of the observations in the remaining thirteen patients are shown in Table II (see previous page), and Figs 6 and 7 are examples of typical studies in two patients (Cases 29 and 1).

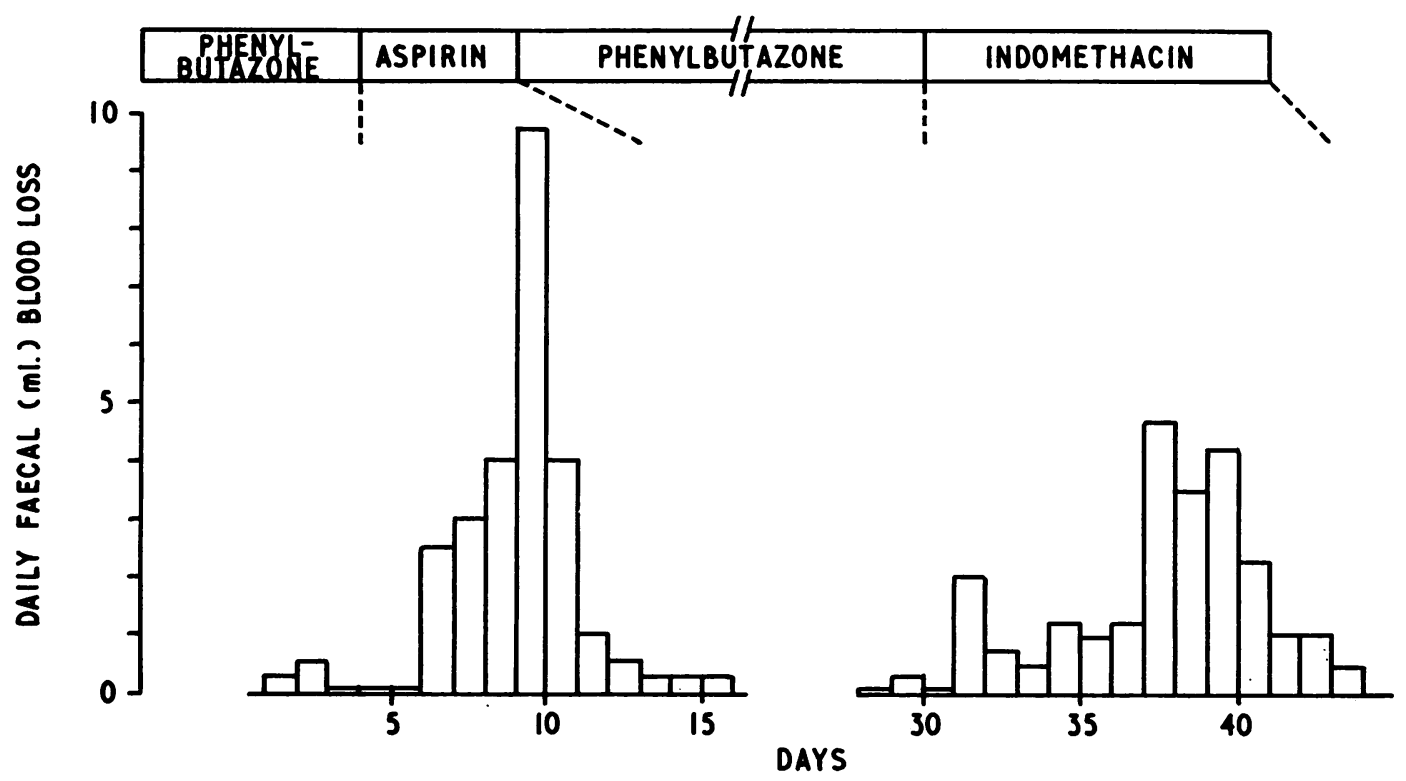

Fig. 6.-Male patient aged 76 with degenerative joint disease who showed bleeding on both aspirin and indomethacin (Case 29) See also Table II.

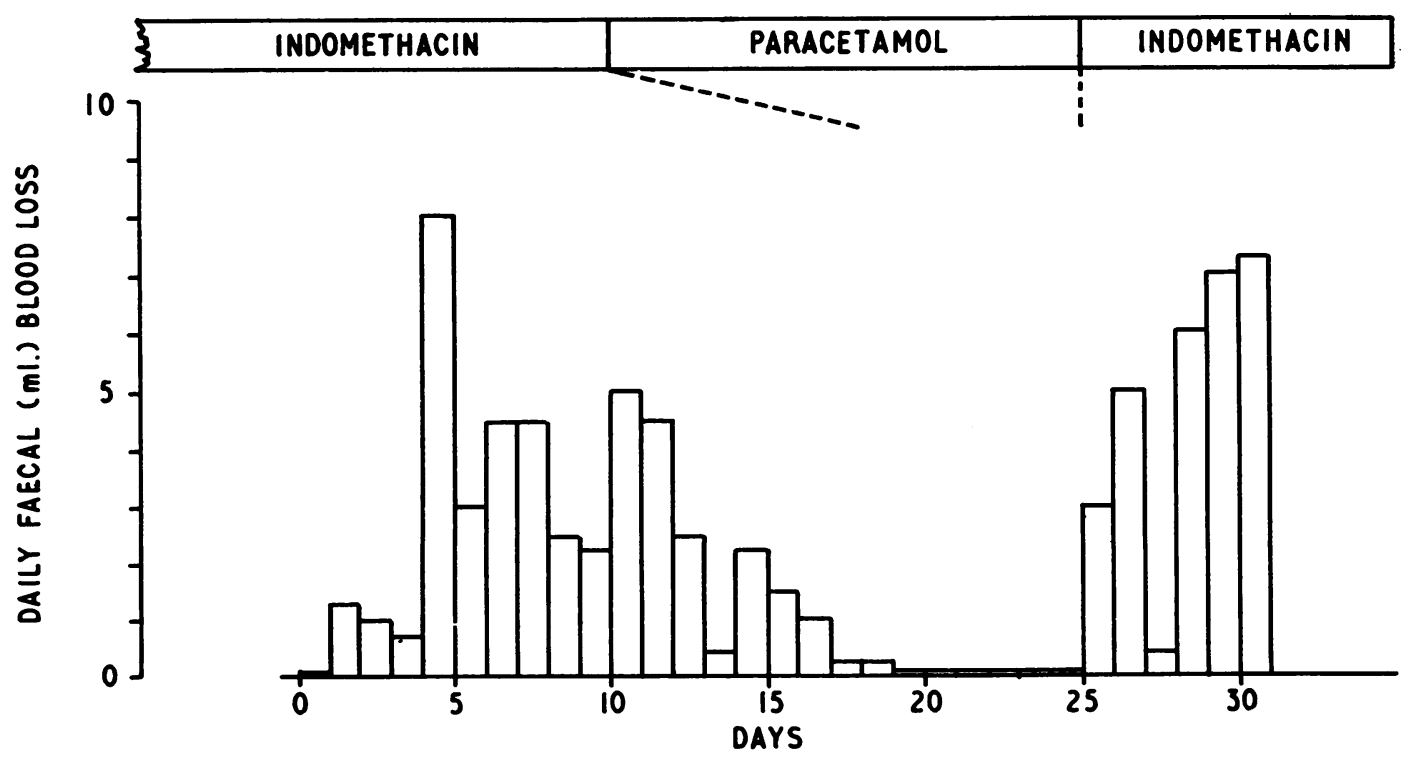

Fig. 7.-Male patient aged 35, allergic to aspirin, showed bleeding on indomethacin but not on paracetamol (Case 1). See also Fig. 2 and Table II. 
One of the thirteen patients (Case 1) was allergic to aspirin. Of the remaining twelve patients, all but one (Case 9) bled significantly after aspirin, the mean loss being $5.9 \mathrm{ml}$. blood per day of treatment with aspirin.

After indomethacin six patients (Cases 26, 18, 4, $30,31,19)$ did not bleed at all, two (Cases 25 and 27) showed a questionable response (less than $2 \mathrm{ml}$. per day of treatment), and five (Cases 1, 9, 28, 29, 32) showed significant and reproducible bleeding (between 2 and $4 \mathrm{ml}$. blood loss per day of treatment), the mean loss being $1 \cdot 2 \mathrm{ml}$. per day of treatment.

\section{Discussion}

The clear subjective preference for indomethacin expressed by the patients taking part in the doubleblind controlled trial contrasts with the comparative failure to show objective improvement by increased strength of grip or change in the erythrocyte sedimentation rate in all but a few. It is of interest that a similar discrepancy was noted in some of the early trials of phenylbutazone (Hart and Johnson, 1952), although this drug is now universally acknowledged to have a powerful anti-rheumatic action. This discrepancy has been a regular experience in previous (unpublished) short-term comparative trials of this sort in which aspirin, an effective drug, was compared with drugs which had been offered for clinical trial but were found to be ineffective. In a previous study of approximately 400 normal subjects and patients including 226 with normal digestive tracts (Wood, 1963) we found that over 70 per cent. of subjects lose measurable quantities of blood in their stools when taking aspirin. This is usually not more than $6 \mathrm{ml}$. per day of treatment, but a few patients, about one in twenty, are extremely susceptible to this effect of aspirin and may lose $20 \mathrm{ml}$. or more per day of treatment. Of the thirteen patients who responded satisfactorily to indomethacin therapy, all except one were shown to bleed after taking aspirin. After indomethacin, six of them did not bleed at all, two showed questionable mild bleeding, and five showed significant and reproducible blood loss.

Among those who were not included in the studies of gastrointestinal bleeding induced by indomethacin, two had to undergo emergency laparotomy - one for major gastrointestinal haemorrhage, and the other for gastric perforation. In both instances there were other possible reasons for these lesions of the upper bowel, but it must be assumed that indomethacin contributed to these events. It is of interest that phenylbutazone and corticosteroids do not cause the symptomless occult bleeding which is associated with the administration of aspirin (Scott,
Porter, Lewis, and Dixon, 1961; Wood, 1963); on the other hand, both these drugs may provoke gastric or duodenal ulceration that may lead to overt major haemorrhage. In contrast, there is no good evidence that aspirin can actually cause peptic ulcer. Indomethacin would appear to occupy an intermediate position-it can cause symptomless occult bleeding, and also can cause major lesions of the upper bowel.

Since this trial was started the fomulation of the drug had been changed from a tablet to an encapsulated powder, and preliminary results suggest that when given in capsule form lower doses are effective and toxic effects much less frequent.

\section{Summary}

This paper describes the use of the new compound indomethacin in rheumatic diseases. The therapeutic effectiveness of the drug was shown by a double-blind controlled trial on 22 patients, and a further 33 patients mainly suffering from rheumatoid arthritis were treated with this drug over periods extending from 4 to 40 weeks.

Though the drug is effective in controlling pain and stiffness, there was a fairly high incidence of headache and giddiness; this was partially overcome by starting with a low dosage which was then gradually increased. In addition, the drug may cause gastrointestinal bleeding in some patients, though less frequently than aspirin; two patients had major gastrointestinal complications while being treated with indomethacin.

Supplies of indomethacin were provided by Dr. J. F. Merry of Merck, Sharp and Dohme, Ltd. Dr. Francis Bach kindly allowed us to include two patients under his care. We should also like to thank our clinic Staff nurses Mrs. Ellis and Mrs. Wagg, S.R.N., for their help.

\section{REFERENCES}

American Rheumatism Association Proceedings (1963). Arthr. and Rheum., 6, 281, 290, 295, 297.

Bross, I. (1952). Biometrics, 8, 188.

Hodgkinson, R. (1963). Personal communication.

Hart, F. Dudley, and Boardman, P. L. (1963). Brit. med.J., $2,965$.

—_ and Johnson, A. M. (1952). Lancet, 2, 43.

Joyce, C. R. B. (1961). Ann. rheum. Dis., $20,78$.

Ropes, M. W., Bennett, G. A., Cobb, S., Jacox, R., and Jessar, R. A. (1957). Ibid., 16, 118.

Scott, J. T., Porter, I. H., Lewis, S. M., and Dixon, A. St. J. (1961). Quart.J. Med., 30, 167.

Stone, A. C. (1962). Personal communication. 
Wood, P. H. N. (1963). In "Salicylates-an International Symposium", ed. A. St. J. Dixon, B. K. Martin, M. J. H. Smith, and P. H. N. Wood, p. 194. Churchill, London.

--, Harvey-Smith, E. A., and Dixon, A. St. J. (1962). Brit.med.J., 1, 669.

\section{Indométhacine dans les maladies rhumatismales Un essai clinique contrôlé}

\section{RÉSUMÉ}

Cet article décrit l'emploi d'un nouveau composé, indométhacine, dans les maladies rhumatismales. L'éfficacité thérapeutique de ce médicament fut démontrée par un essai contrôlé par la méthode de double-blind chez 22 malades; de plus, 33 autres malades, atteints surtout d'arthrite rhumatismale, furent traités par ce produit pendant des périodes allant de 4 à $\mathbf{4 0}$ semaines.

Bien que ce médicament soit efficace contre la douleur et la raideur, la céphalée et le vertige survenaient assez souvent; on surmontait en partie ces inconvénients en commençant par de petites doses et en les augmentant progressivement. Chez certains malades ce produit peut causer des hémorrhagies gastro-intestinales, bien que moins souvent que l'aspirine; deux malades ont eu de majeures complications gastro-intestinales pendant le traitement par l'indométhacine.

Après le commencement de cet essai la présentation du médicament a été changée et une poudre en capsule a remplacé le comprimé. Les résultats provisoires indiquent que lorsque le produit est administré en capsule, des doses plus faibles sont efficaces et les effets toxiques sont plus rares.

\section{Indometacina en enfermedades reumáticas Investigación clínica controlada}

\section{SUMARIO}

Este artículo describe el empleo de un nuevo compuesto, indometacina, en enfermedades reumatoides. $\mathrm{Su}$ eficacidad terapéutica fué demostrada por una investigación controlada por el método de double-blind en 22 enfermos; además, 33 otros enfermos sufriendo en su mayoría de artritis reumatoide, fueron tratados con este producto durante períodos de 4 a 40 semanas.

Aunque la indometacina fuese eficaz contra el dolor y la rigidez, cefalalgia y mareo occurrían con bastante frecuencia; para superar en parte estas dificultades se empezaba con pequeñas dosis aumentándolas progresivamente. En ciertos enfermos este compuesto producía hemorragias gastrointestinales, aunque con menos frecuencia que la aspirina; dos enfermos sufrieron mayores complicaciones gastrointestinales durante el tratamiento con indometacina.

Después de haber empezado esta investigación, la presentación del medicamento fué cambiada de comprimidos a polvos encapsulados. Los resultados preliminares indican que cuando se administra el producto en forma de cápsulas, dosis menores son eficaces y efectos tóxicos son menos frecuentes. 